\title{
Black Coral: History of a Sustainable Fishery in Hawai' ${ }^{1}{ }^{1}$
}

\author{
Richard W. Grigg ${ }^{2}$
}

\begin{abstract}
The black coral fishery in Hawai'i has been sustainable for the past 40 yr. The fishery began in 1958, shortly after its discovery off Lahaina, Maui, by Jack Ackerman and Larry Windley, who later formed the company Maui Divers of Hawaii. Since that time, the black coral jewelry industry has gradually expanded and is valued in Hawai'i today at about $\$ 15$ million at the retail level. In the 1970s, studies of the population dynamics of the major species established growth, recruitment, and mortality rates and led to the development of management guidelines including recommendations for a minimum size and maximum sustained yield. Results of a recent survey in 1998, reported in this paper, show that rates of recruitment and growth are near steady state and appear to account for the long-term stability of the fishery. However, recent technological advances and potential increases in demand could lead to increased rates of harvest. Should this happen, more stringent regulations may be required to avoid overexploitation of the resource.
\end{abstract}

This paper outlines the history of the black coral fishery in Hawai' $i$ and reports the results of a recent survey of the Maui black coral bed conducted in 1998. The objectives of the survey were to obtain measures of abundance, recruitment, and size frequency of the two main species, Antipatbes dichotoma Pallas and $A$. grandis Verrill, and to evaluate the sustainability of the resource. In brief, the goal was to reassess maximum sustainable yield of black coral in the 'Au'au Channel bed off Maui.

\section{History of the Black Coral Fisbery in Hawai $i$}

The black coral fishery in the Hawaiian Islands began in 1958 when a large bed of black coral consisting primarily of $A$. dicbotoma and $A$. grandis was discovered off Lahaina, Maui, by Jack Ackerman and Larry Windley (Grigg 1965). The site of their original discovery was

\footnotetext{
1 This research was supported by a grant (144898210-98-M517) from the U.S. Fish and Wildlife Service Office of Scientific Authority. Manuscript accepted 6 November 2000.

2 Department of Oceanography, University of $\mathrm{Ha}-$ waiłi at Mänoa, Honolulu, Hawaiłi 96822.
}

Pacific Science (2001), vol. 55, no. 3:291-299

(C) 2001 by University of Hawai ${ }^{*} \mathrm{i}$ Press

All rights reserved
$4.8 \mathrm{~km}$ west of Lahaina in the middle of the 'Au'au Channel between Maui and Lāna'i at depths of 30-90 m (Figure 1).

Subsequent exploration by these pioneers showed that the 'Au'au Channel bed extended for many linear kilometers along steep topographic drop-offs in the channel between Maui and Lanna'i. Recognizing the value and extent of their find, Ackerman and Windley started a small business in Lahaina, Maui, in 1958, for the production and sale of black coral jewelry. They named their small company Maui Divers of Hawaii (Stewart 1962).

The harvest of black coral in Hawai'i has traditionally been carried out by scuba divers. In the early years of the fishery, divers harvested black coral by cutting or breaking the coral from the bottom with an ax and sledge. They then tied the coral to their boat anchor lines (Figure 2). At the end of the dive, the anchor and coral "trees" were buoyed to the surface by inflating lift bags on the bottom. Lift bags are still used today to float the coral to the surface, but the divers no longer anchor over the beds. Instead, they use a "free boat" method in which the boat follows lift bags as they reach the surface. The divers ascend with their last lift bag (Figure 3) and decompress while the boat drifts above them on the surface. On an average dive, two to four trees (colonies) of black coral are harvested; each colony weighs between 2 and 

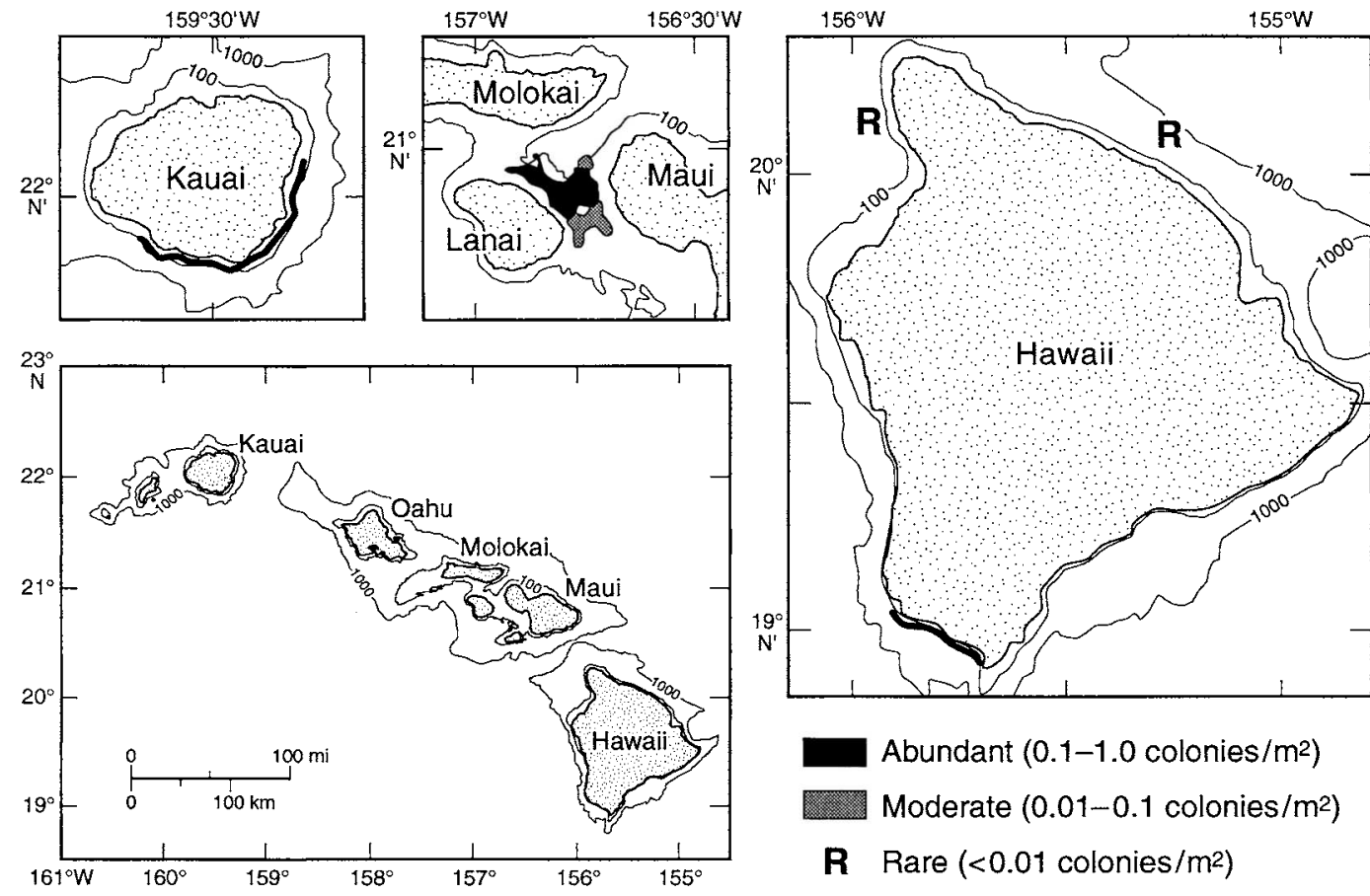

Abundant $\left(0.1-1.0\right.$ colonies $\left./ \mathrm{m}^{2}\right)$

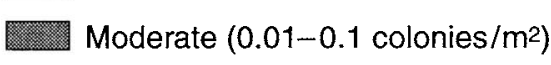

R Rare $\left(<0.01\right.$ colonies $\left./ \mathrm{m}^{2}\right)$

Figure 1. Map showing the location of black coral beds in Hawai' $i$.

$5 \mathrm{~kg}$ (5-10 pounds). The total weight of coral harvested per dive, per diver, averages $\sim 10 \mathrm{~kg}$ (22 pounds) and is valued in today's market at $\$ 25 /$ pound. The depth range of harvested black coral is $40-75 \mathrm{~m}$ (130-250 feet).

Between 1960 and 1970, the black coral jewelry industry in Hawai'i grew steadily. By 1969 , about one dozen small companies had joined Maui Divers and together they produced about $\$ 2$ million in gross sales of black coral jewelry. Although the economic potential of the industry had been firmly established by that time, little was known about the ecology of the resource and whether or not natural growth rates of the coral were sufficient to sustain commercial harvest rates. In response to this need for information, in 1970, a major long-term research program began at the University of Hawai'i on the ecology of precious corals. The study included surveys to establish the distribution and abundance of all black coral beds in the state and to determine size limits and optimum harvest yields based on measures of abundance, growth, natural mortality, and recruitment.

During the next $5 \mathrm{yr}$, two large black coral beds were identified in the state and assessed: the Maui bed and a smaller bed off Kaua'i. Both areas were mapped and estimates of maximum sustained yield (MSY) were calculated. Mapping was based on the catch records of commercial divers, as well as about 100 dives by the University of Hawai' $i$ research team (R. Grigg, S. Dollar, M. Palmgren, J. Angel, and G. Galiher). The areal coverage of the Maui and Kaua'i beds was determined to be $1.7 \mathrm{~km}^{2}$ and $0.4 \mathrm{~km}^{2}$, respectively (Figure 1) (Grigg 1976). Corresponding estimates of MSY for the two beds were found to be $6174 \mathrm{~kg} / \mathrm{yr}$ and $1480 \mathrm{~kg} / \mathrm{yr}$. MSY values were calculated using a Beverton and Holt yield production model (Beverton and Holt 1957, Grigg 1976).

Actual values of MSY recommended to state and federal agencies $(5000 \mathrm{~kg} / \mathrm{yr}$ and $1250 \mathrm{~kg} / \mathrm{yr}$, respectively) were about $15 \%$ less than the yield per recruit based on the model 


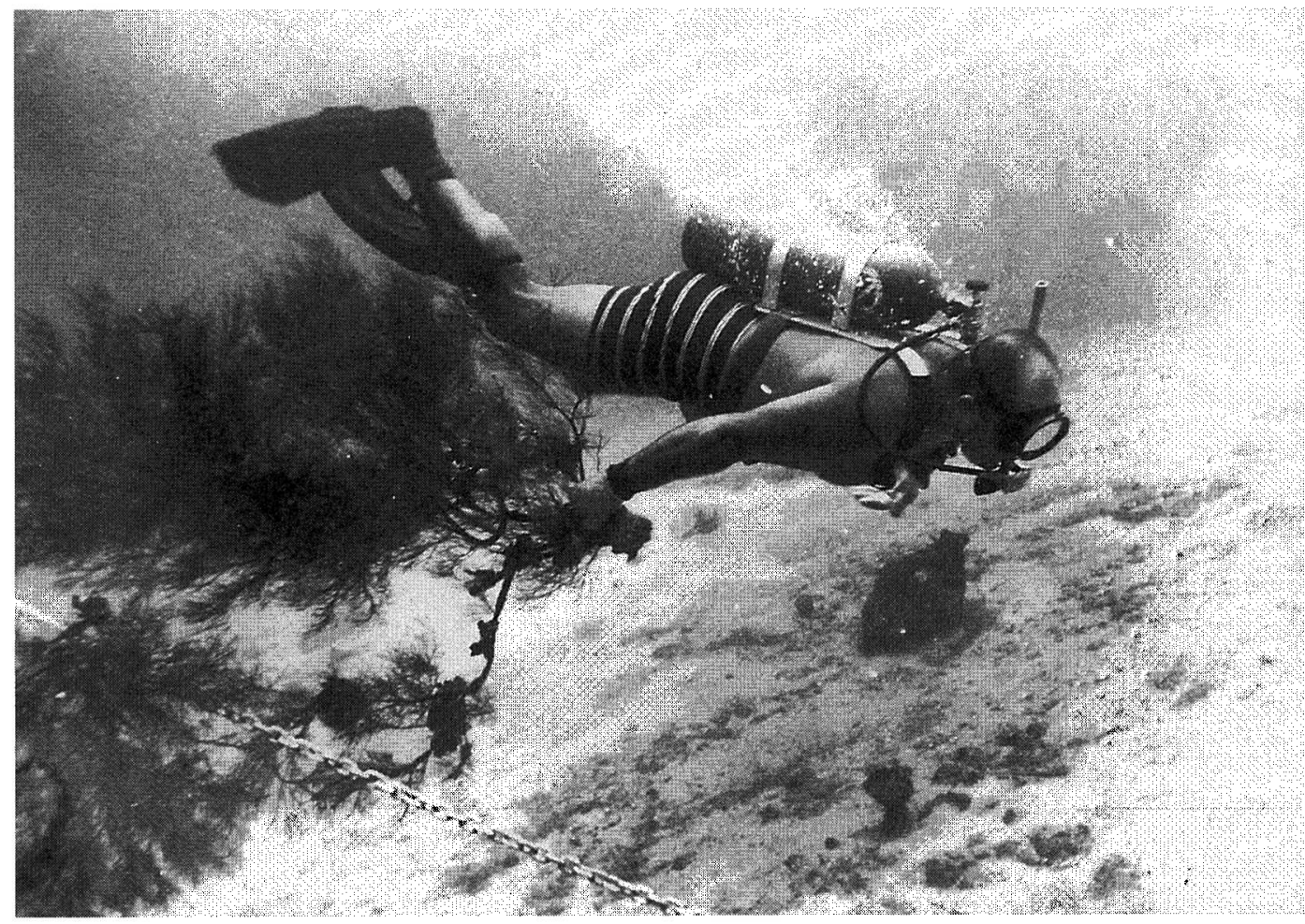

Figure 2. In the 1960s, black coral was harvested with axes and sledges. Colonies were tied to the anchor line and then buoyed to the surface.

estimates (900 g per recruit versus $1050 \mathrm{~g}$ per recruit [see Grigg 1976]). This downward revision was recommended to permit the harvest of slightly smaller colonies consistent with traditional fishing practices. Basically, it allowed the divers to continue their past practice of harvesting colonies down to a height limit of 48 inches $(1.2 \mathrm{~m})$. Industry demand for colonies less than $1.2 \mathrm{~m}$ is low because most branches of colonies less than that height are too small in diameter to produce jewelry. Hence the $1.2-\mathrm{m}$ size limit can be considered an "optimum yield" (Gulland 1977). The size limit corresponding to optimum yields of 5000 and $1250 \mathrm{~kg} / \mathrm{yr}$ determined by the model is $1.2 \mathrm{~m}$ for both $A$. dichotoma and $A$. grandis. The same size limit can be applied to both species because of similarity in their growth rates: $6.42 \mathrm{~cm} / \mathrm{yr}$ and $6.12 \mathrm{~cm} / \mathrm{yr}$, respectively (Grigg 1976).

In the years following this period of re- search in the $1970 \mathrm{~s}$, the State of Hawai' $i$ enacted a draft regulation for a minimum size limit of 48 inches $(1.2 \mathrm{~m}$ ) (Draft Regulation 48). No weight quotas were adopted because the size limit was considered a de facto proxy for MSY and was more easily enforced. During the 1980s and 1990s, black coral divers and industry buyers (jewelry producers) voluntarily complied with Draft Regulation 48.

During the 1980s, several major changes took place that affected both the black coral fishery and industry in Hawai'i. The first change was a slow but steady improvement in the efficiency in cutting and polishing black coral jewelry products. Cliff Slater (pers. comm.), CEO of Maui Divers, the largest precious coral jewelry company in the state, estimated that technological improvement in coral processing during the 1980 s led to a several hundred percent decrease in the amount of coral consumed to produce the 


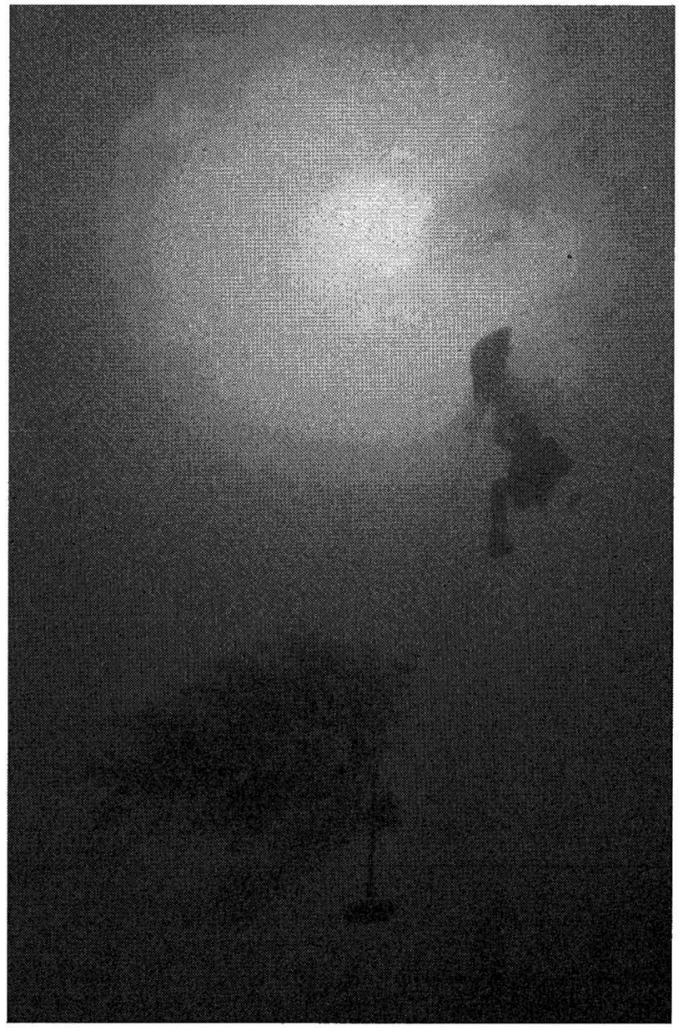

Figure 3. Today, float bags are used by the black coral divers to float coral colonies (trees) to the surface.

same value of finished product. Part of the improved efficiency was the use of smaller amounts of coral to sell larger amounts of gold in the form of settings. The use of large pieces of black coral for manufacture of items such as bolo ties and cuff links was gradually phased out.

A second major change in the black coral industry that began in the $1980 \mathrm{~s}$, and is continuing today, is the importation of worked (cut and polished) black coral from Taiwan. In the 1980s, the number of pieces of black coral jewelry imported to the United States (primarily Hawai ${ }^{i}$ ) ranged between 260,000 and 616,000 items of polished jewelry per annum (Table 1). During that period, the amount of raw material processed in Taiwan was about 70 tons per year, most of which originated in the Philippine Islands (Carleton and Philipson 1987). Average consumption of
TABLE 1

Annual Records of Worked Black Coral Pieces Imported into the United States

\begin{tabular}{lc}
\hline \hline Year & No. of Pieces \\
\hline 1982 & 408,773 \\
1983 & 411,723 \\
1984 & 260,879 \\
1985 & 511,268 \\
1986 & 616,978 \\
1987 & 608,288 \\
1988 & 425,237 \\
1989 & 522,703 \\
1990 & 279,457 \\
1991 & 183,463 \\
1992 & 354,656 \\
1993 & 209,724 \\
1994 & 606,261 \\
1995 & 155,194 \\
1996 & 330,496 \\
1997 & 293,473 \\
1998 & 274,188 \\
\hline
\end{tabular}

Source: Ed Green, World Conservation Monitoring Centre, 219 Huntington Road, Cambridge, U.K.

raw black coral by the industry in Hawai' $i$ during the same period was less than $2000 \mathrm{~kg} / \mathrm{yr}$ (Oishi 1990) (Table 2).

Landings of black coral reported harvested in Hawaiian waters over the past $16 \mathrm{yr}$ are summarized in Table 2 and presented graphically in Figure 4. Virtually all of this coral was harvested from the Maui bed. Reported harvest from other beds in the state off Kaua' $i$ and the Big Island has been incidental during this period. The mean annual harvest from the Maui beds based on reported landings to the Hawai'i Division of Aquatic Resources, Department of Land and Natural Resources, is $1014 \mathrm{~kg} / \mathrm{yr}$ (2232 pounds) (Oishi 1990). This amount of coral is far below the MSY of $5000 \mathrm{~kg} / \mathrm{yr}(11,000$ pounds/yr) for the Maui beds in the 'Au'au Channel as discussed earlier.

Since about 1980 to the present, the majority of black coral sold in Hawai' $i$ has, in fact, been worked (cut, processed, and polished) coral produced in Taiwan that originated in the Philippine Islands. Most of this product is in the form of beads in necklaces, bracelets, and rings. Smaller amounts of cabochons are also imported. The primary 
TABLE 2

Landings of Black Coral in Hawai $\mathrm{i}$

\begin{tabular}{|c|c|c|c|c|}
\hline \multirow[b]{2}{*}{ Year } & \multicolumn{2}{|c|}{ Weight } & \multirow[b]{2}{*}{$\%$ Sold } & \multirow[b]{2}{*}{ Value $(\$ / 1 b)$} \\
\hline & $\mathrm{lb}$ & $\mathrm{kg}$ & & \\
\hline 1981 & 158 & 72 & 67 & 11.08 \\
\hline 1982 & 945 & 430 & 5 & 20.05 \\
\hline 1983 & 1,911 & 869 & 5 & 16.00 \\
\hline 1984 & 3,150 & 1,482 & 100 & 15.00 \\
\hline 1985 & 308 & 140 & 19 & 14.00 \\
\hline 1986 & 935 & 425 & 100 & 14.34 \\
\hline 1987 & 4,351 & 1,977 & 87 & 15.00 \\
\hline 1988 & 515 & 234 & 39 & 15.00 \\
\hline 1989 & 1,020 & 464 & 100 & 14.41 \\
\hline 1990 & 2,349 & 1,067 & 92 & 14.55 \\
\hline 1991 & 2,305 & 1,048 & 98 & 15.60 \\
\hline 1992 & 2,398 & 1,090 & 97 & 20.00 \\
\hline 1993 & 864 & 393 & 89 & 20.00 \\
\hline 1994 & 4,354 & 1,979 & 97 & 20.00 \\
\hline 1995 & 6,017 & 2,735 & 98 & 20.76 \\
\hline 1996 & 4,865 & 2,211 & 35 & 24.29 \\
\hline 1997 & 1,515 & 689 & 4 & 25.00 \\
\hline
\end{tabular}

Source: Hawai'i Division of Aquatic Resources, commercial catch reports.

species consumed by this production is Cirrbipatbes anguina, popularly known as whip coral (Carleton and Philipson 1987). Cirrbipathes anguina is found at shallower depths than species of Antipatbes and is abundant in many areas of the Indo-West Pacific. The quality of black coral jewelry produced from $C$. anguina is inferior to products fashioned from $A$. dichotoma and $A$. grandis because it is of lower density and the jewelry does not maintain a high luster after several years of wear. In Waikīi today, about $90 \%$ of the black coral products sold are "Taiwan coral."

The infusion of foreign coral along with the improvement in the efficiency and technology of manufacturing Hawaiian raw coral products has combined to keep demand within the sustainable limits of the resource (see Results). Both of these influences on the market have served to conserve the local supply of black coral in Hawai'i and protect local beds from overharvest.

In 1987, black coral was designated the official state gem. This designation served to increase interest in black coral products and helped to stabilize demand for raw material. By the late 1990s, the black coral industry in
Hawai'i (imports and locally produced jewelry), consisting of four major producers and about 100 retailers, was valued at about \$15 million per year (Grigg 1993).

\section{Follow-Up Survey of Black Coral in the Maui Bed}

The first survey of the age frequency of black coral in the Maui bed was conducted in 1975 (Grigg 1976). The 1975 data set provides a baseline for the 1998 survey.

\section{MATERIALS AND METHODS}

Most of the stations surveyed in both studies were located in the same general area in the middle of the 'Au'au Channel, between Maui and Lāna'i. In 1998, five dives were completed: three along the Stonewall section of the Lahaina Roads Reef $\left(20^{\circ} 52^{\prime} 45^{\prime \prime} \mathrm{N}\right.$, $156^{\circ} 43^{\prime} 45^{\prime \prime}(\mathrm{W})$, one at a reef drop-off known as Circus $\left(20^{\circ} 52^{\prime} 45^{\prime \prime} \mathrm{N}, 156^{\circ} 45^{\prime} 45^{\prime \prime} \mathrm{W}\right)$, and another at the Most Radicals Reef $\left(20^{\circ} 53^{\prime} 10^{\prime \prime} \mathrm{N}, 156^{\circ} 44^{\prime} 52^{\prime \prime} \mathrm{W}\right)$. All stations but Circus were surveyed in the 1975 study.

The age frequency distribution for the population was constructed by swimming parallel to an isobath at $50 \pm 5 \mathrm{~m}$ and measuring the height of every colony encountered at each station. Measurements were taken with a 2.1-m rod and recorded on an underwater writing slate. Measurement error, based on replicate measures of the same colony, was about $\pm 5 \%$. Size was converted to age by dividing the height of both species by their annual growth rates (Grigg 1976). Approximately $95 \%$ of the population was $A$. dicbotoma; therefore colonies of $A$. grandis were lumped into the age frequency distribution of $A$. dichotoma. Both species have similar rates of growth.

All five stations have been harvested with about the same intensity over the last $40 \mathrm{yr}$ (Robin Lee, pers. comm.), and all exhibit a similar pattern of abundance and age distribution. The data for all five stations in $\mathbf{1 9 9 8}$ were therefore pooled, making up a single sample of 211 colonies. The data from this sample population were compared with the data from the sample population in 1975 . In 


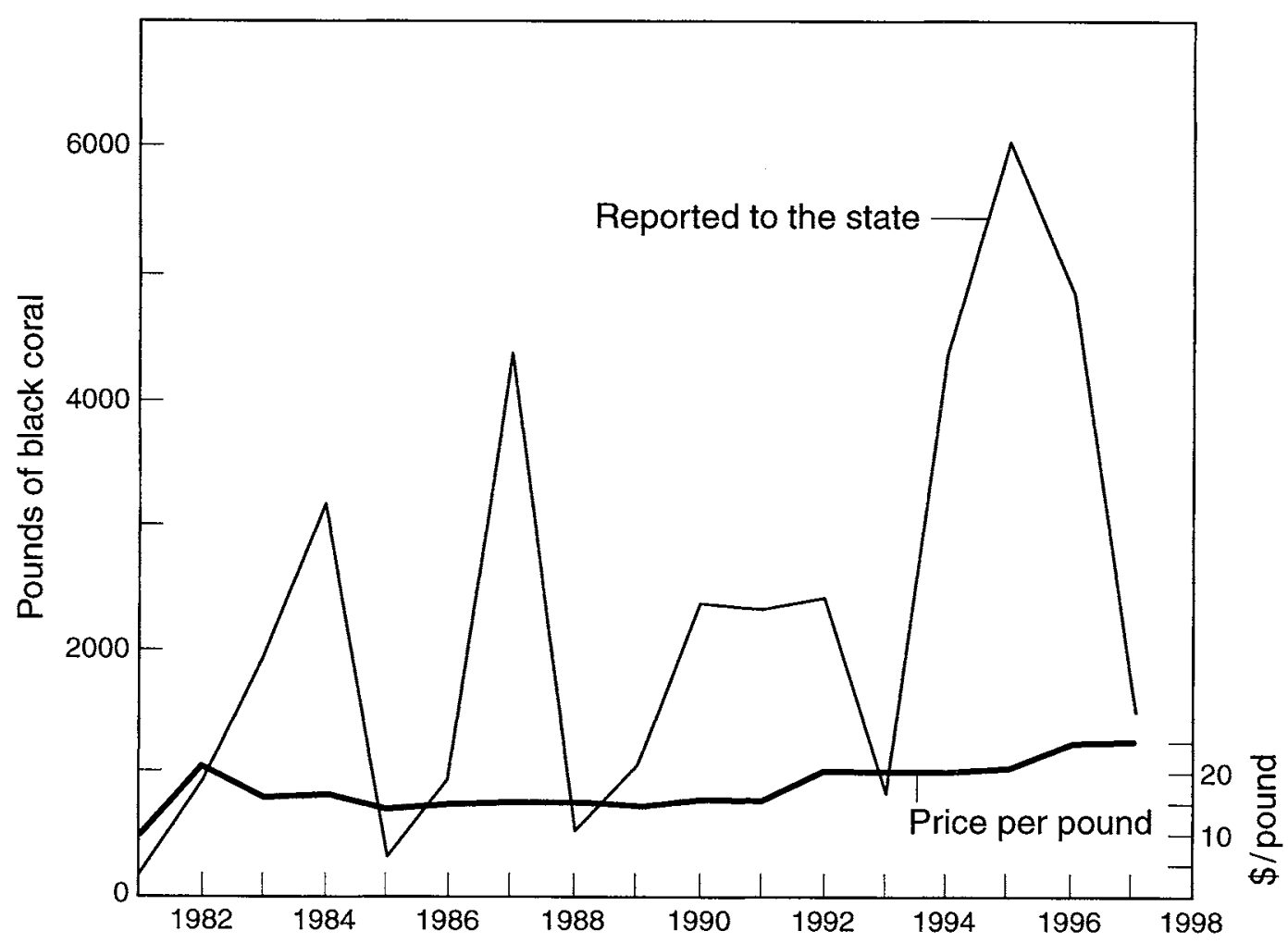

Figure 4. Annual reported harvest and price of raw black coral in Hawai i (Hawai'i Department of Aquatic Resources commercial catch records). The large year-to-year variability is caused primarily by stockpiling by divers and irregular buying by the jewelry producers. The divers usually do not report harvest until they sell the coral.

both sample populations, mortality was calculated as the coefficient of linear regression of the natural logrithm of year class abundance $(n)$ versus time (Beverton and Holt 1957, Grigg 1976). MSY was calculated using the Beverton and Holt model (see Grigg [1976] for details).

\section{RESULTS}

The age frequency distributions of sample populations in 1975 and 1998 exhibit a remarkably similarity (Figure 5). Except for the first $2 \mathrm{yr}$, which are underrepresented in both surveys, year class abundance exhibits a pattern of more-or-less steady decline from year 3 to the oldest colonies in the population. The underrepresentation of young colonies (age $0-2$ yr) is likely an artifact of the diffi- culty in seeing young colonies less than 5-10 $\mathrm{cm}$ in height because larvae frequently settle in shaded cracks and interstices of the reef. Although there is some small fluctuation between age classes, compared with other invertebrates, the overall population structure is relatively stable (Coe 1956). Assuming steady-state recruitment, the rate of decline among progressively older year classes is a measure of mortality due to natural processes and harvesting (Beverton and Holt 1957). The rate of mortality in 1975 was $6.8 \%$ compared with $8.4 \%$ in 1998 , an increase of almost $2 \%$, most likely due to harvesting during the interim. The equations for 1975 and 1998 for mortality are $y=2.41-0.068 x$ and $y=2.89-0.084 x$, respectively. Average annual recruitment, as indicated by the $y$ intercept, is almost the same in both 1975 and 


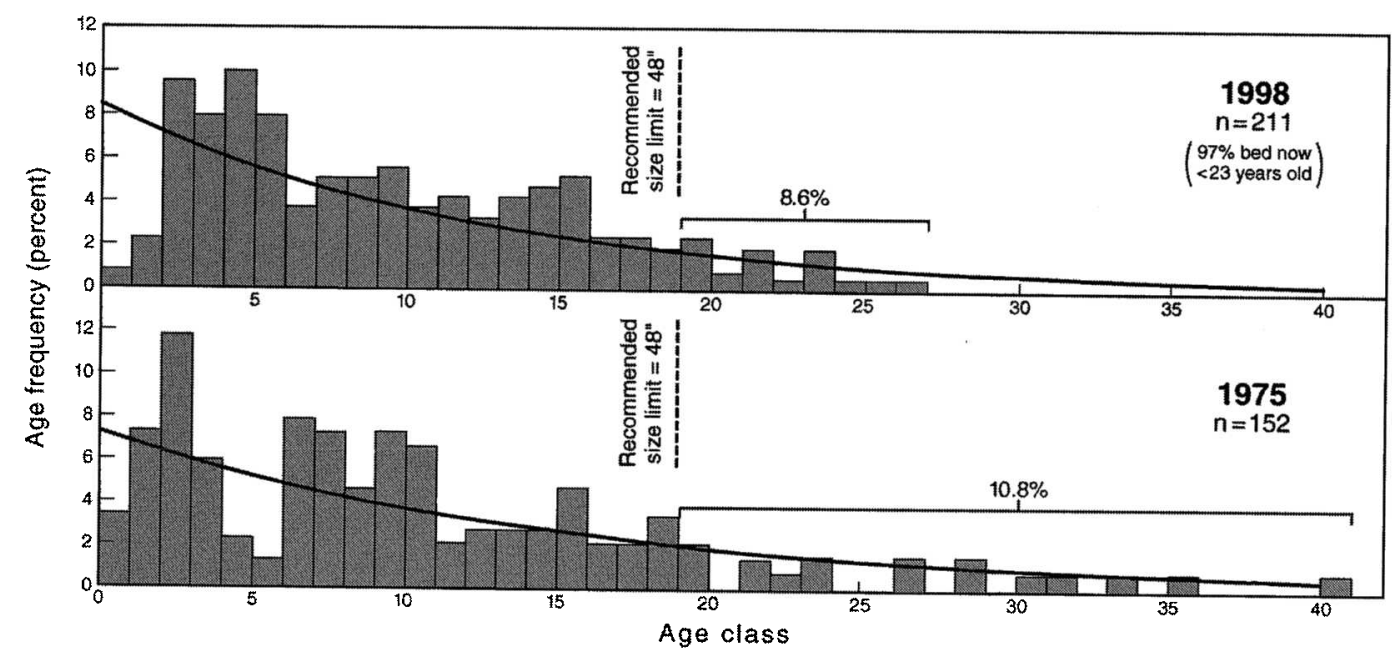

FIGURE 5. Age frequency distributions of black coral off Maui in 1975 and 1998.

1998, strongly suggesting that harvesting during the intervening years had no statistically significant effect on recruitment.

The only important difference between the age structure of the 1975 and the 1998 sample populations is the fewer number of large colonies over age $19: 8.6 \%$ in 1998 versus $10.8 \%$ in 1975 , a decrease of $2.2 \%$. However, it should be noted that the $2.2 \%$ of the overall population represents $20 \%$ of colonies over the minimum size and no colonies over age 27 (1.7 m [5.6 feet]) were present in the 1998 sample population. This shift to a younger age frequency is clearly a result of harvesting. Nevertheless, the lack of any substantial difference in the age structure of colonies less than $19 \mathrm{yr}$ old, which represents the recommended size limit of $1.2 \mathrm{~m}$, indicates excellent compliance by the divers with this management guideline during the past two dozen years.

Perhaps the most remarkable result of the study is the degree to which the population has replaced itself since 1975. In 1998, $23 \mathrm{yr}$ later, $97 \%$ of the colonies measured in the sample area were less than $23 \mathrm{yr}$ old (Figure 5). This means that the bed in 1998 consists almost entirely of new colonies that have recruited since the 1975 survey. The regeneration time of the bed is equivalent to the age of its oldest colonies. This result is due to relatively constant recruitment.

\section{DISCUSSION AND CONCLUSIONS}

Although the age frequency distribution of the 1998 population of black coral appears to have changed, with fewer large, old colonies, the total mortality (natural plus fishing) has only increased about 2\%. Colonies larger than the minimum size have been reduced by about $20 \%$. Most important, the rate of recruitment has remained nearly constant. This means that current rates of harvest are sustainable. In fact, $97 \%$ of the populations sampled in the 'Au'au Channel bed have recruited since 1975. Steady recruitment may depend in part on deeper portions of the bed at depths between 75 and $110 \mathrm{~m} \mathrm{(245-360}$ feet), which remain in a virgin (unfished) state.

The results of this analysis suggest that the current levels of harvest of black coral in Hawai' $i$ are sustainable. However, a number of potential developments could change the current balance between supply and demand. The first is new technology associated with mixed-gas diving, which could encourage new divers to dive deeper with longer bottom time. New decompression tables, in which inert gases (nitrogen and helium) are switched and 
pure oxygen is used at 30 feet $(9.1 \mathrm{~m})$ and shallower, have the potential of greatly shortening decompression time, thereby encouraging longer and deeper dives. Longer dives translate into a potential increase in fishing pressure. The use of submersibles or remotely operated vehicles also poses a potential threat in this regard. New divers or fishermen may not have the same conservation ethic as the "old-timers" in Lahaina.

Such developments could be problematic if markets for the sale of raw black coral were to be aggressively pursued outside of the state of Hawaici. Also, if current imports of cut and polished black coral from Taiwan into Hawai' $i$ were to decrease substantially, demand for locally harvested raw material could suddenly increase. As mentioned previously, about $90 \%$ of the black coral jewelry currently sold in Waikiki represents imported products. This jewelry is universally less expensive than high-quality domestic black coral, but it also serves to reduce pressure (demand) for local raw material.

Taken together, these potential changes could substantially increase the demand for locally produced black coral. Historically, harvest levels have been considerably below MSY, but fewer large, heavier colonies remain in the population and recruitment may have held up because virgin populations exist between 75 and $110 \mathrm{~m}$. Therefore, if harvest rates increase in the future, particularly at greater depths, more stringent guidelines may be necessary to avoid overexploitation of the resource. A larger minimum size or a smaller MSY are two options. Another is limited entry, restricting permits to long-term black coral fishermen. The state has recently moved in this direction by formally granting (grandfathering) the existing five permit holders a more lenient size limit of 36 inches $(0.9 \mathrm{~m})$. However, new entrants to the fishery are required to abide by the 48 -inch $(1.2-\mathrm{m})$ size limit.

Clearly it will be necessary to monitor the future status of the resource at periodic intervals, perhaps every $3 \mathrm{yr}$. This can be done by measures of the age frequency of sample populations in harvested areas and periodic reassessments of MSY. The size of harvested coral is also a key parameter to monitor closely. Finally, more research on the biology of black coral is needed, particularly concerning reproductive biology (age at first reproduction), larval biology, and recruitment. The future stability of both the resource and the industry depends on continued compliance with existing management measures, as well as monitoring to ensure that they are working. Should there be a substantial decrease in recruitment, it may be necessary to apply more stringent guidelines.

\section{ACKNOWLEDGMENTS}

I thank Roddy Gabel of the U.S. Fish and Wildlife Service for his assistance in procuring financial support to conduct this research. In the field, Dennis Pesch provided technical advice and accompanied the principal investigator on all deep dives. Robin Lee and Roland Sonoda also assisted in the field by identifying the location of the black coral beds off Lahaina and also served as buddy divers during the deep transects. Ed Green of the World Monitoring Conservation Centre provided data for CITES Records for the international trade in black coral. For local records of black coral harvest, I thank Francis Oishi of the Hawai'i Division of Aquatic Resources for his assistance and help with the history of the fishery. Cliff Slater also provided statistical data for the study and knowledge of the economic history of the fishery and industry.

\section{Literature Cited}

Beverton, R. J. H., and S. Holt. 1957. On the dynamics of exploited fish populations. Fish. Invest. Minist. Agric. Fish. Food (G.B.), Ser. II 19:1-553.

Carleton, C. C., and P. W. Philipson. 1987. Report on a study of the marketing and processing of precious coral products in Taiwan, Japan and Hawaii. South Pacific Forum Fisheries Agency. FFA Report No. 87/1333. 49 pp.

Coe, W. R. 1956. Fluctuations in populations of littoral marine invertebrates. J. Mar. Res. 15:212-232. 
Grigg, R. W. 1965. Ecology of black coral in Hawaii. M.S. thesis, University of Hawai' $i$ at Mānoa, Honolulu.

$$
\text { 1976. Fishery management of pre- }
$$
cious and stony corals in Hawaii. UNIHISEAGRANT-TR-77-03. 48 pp.

- 1993. Precious coral fisheries of Hawaii and the U.S. Pacific Islands. Mar. Fish. Rev. 55:50-60.

Gulland, J. A. 1977. The management of marine fisheries. University of Washington Press, Seattle.

Oishi, F. 1990. Black coral harvesting and marketing activities in Hawaii-1990. Division of Aquatic Resources, Department of Land and Natural Resources, State of Hawai'i.

Stewart, J. 1962. The Hawaiian black coral story. Parts I and II. Lapidary, pp. 388, 490. 